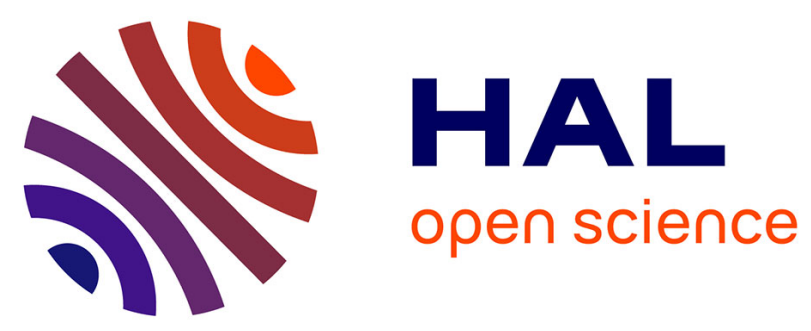

\title{
High-Yield Formation of Substituted Tetracyanobutadienes from Reaction of Ynamides with Tetracyanoethylene.
}

Marie Betou, Nicolas Kerisit, Esme Meledje, Yann R Leroux, Claudine Katan, Jean-François Halet, Jean-Claude Guillemin, Yann Trolez

\section{To cite this version:}

Marie Betou, Nicolas Kerisit, Esme Meledje, Yann R Leroux, Claudine Katan, et al.. High-Yield Formation of Substituted Tetracyanobutadienes from Reaction of Ynamides with Tetracyanoethylene.. Chemistry - A European Journal, 2014, 20 (31), pp.9553-9557. 10.1002/chem.201402653 . hal01017020

\section{HAL Id: hal-01017020 \\ https://hal.science/hal-01017020}

Submitted on 25 Nov 2016

HAL is a multi-disciplinary open access archive for the deposit and dissemination of scientific research documents, whether they are published or not. The documents may come from teaching and research institutions in France or abroad, or from public or private research centers.
L'archive ouverte pluridisciplinaire HAL, est destinée au dépôt et à la diffusion de documents scientifiques de niveau recherche, publiés ou non, émanant des établissements d'enseignement et de recherche français ou étrangers, des laboratoires publics ou privés. 
Chem. Eur. J., 2014, 20, pp 9553-9557. doi:10.1002/chem.201402653

\title{
High-yield formation of substituted tetracyanobutadienes from reaction of ynamides with tetracyanoethylene
}

\author{
Marie Betou, ${ }^{a}$ Nicolas Kerisit, ${ }^{a}$ Esme Meledje, ${ }^{a}$ Yann R. Leroux, ${ }^{b}$ Claudine Katan, ${ }^{b}$ Jean-François \\ Halet, ${ }^{b}$ Jean-Claude Guillemin ${ }^{a}$ and Yann Trolez* ${ }^{a}$
}

Table of content: Reaction between ynamides and tetracyanoethylene at room temperature in dichloromethane provides tetracyanobutadienes in good to quantitative yields, following a sequence of $[2+2]$ cycloaddition-retroelectrocyclization.

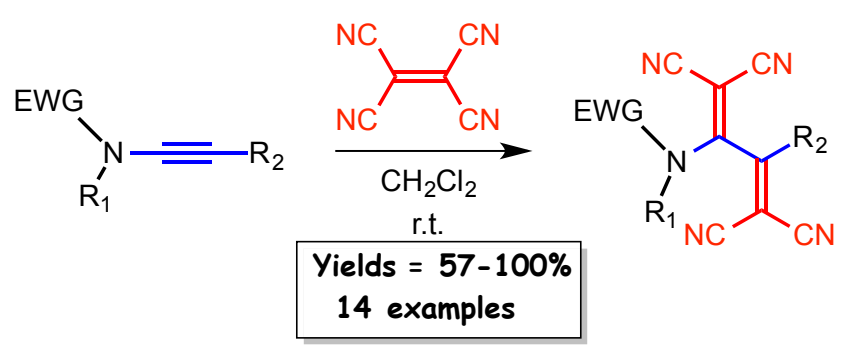

Abstract: The high-yield sequence of [2+2]cycloaddition-retroelectrocyclization of ynamides with tetracyanoethylene (TCNE) is described. The reaction provided tetracyanobutadiene (TCBD) species, which were characterized by various techniques. DFT and TD-DFT calculations were also performed to complement experimental findings.

Keywords: Ynamides, tetracyanoethylene, [2+2]cycloaddition, tetracyanobutadienes

The sequence of [2+2]cycloaddition-retroelectrocyclization (CA-RE) between tetracyanoethylene (TCNE) and alkynyl-transition metal complexes has been known for several decades ${ }^{[1]}$ and has extensively been studied. ${ }^{[2]}$ However, to the best of our knowledge, this reactivity with purely organic alkynes has been discovered only in 1999 with $\alpha$-substituted thienylalkynes. ${ }^{[3]}$ Since then, other alkynes substituted by electron-donating groups (EDG) have been shown to react the same way (Figure 1). ${ }^{[4]}$ This reaction has mostly been popularized by Diederich and co-workers for the last decade. ${ }^{[5]}$ Aniline-, ${ }^{[6]}$ azulene- ${ }^{[7]}$ and heteroazulene-substituted ${ }^{[8]}$ alkynes represent the best examples of this reaction by providing yields over $90 \%$, by simply mixing the two reactants together in a solvent at room temperature. However, the reactivity of TCNE with alkynes directly substituted by an electron donating heteroatom has never been described.

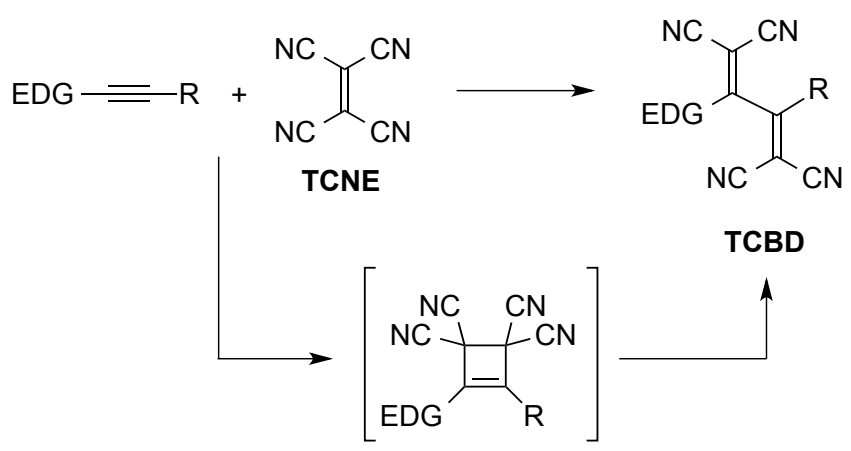

Figure 1. Previous work on [2+2]cycloaddition of TCNE with electron-rich alkynes.

As examples of such compounds, ynamides have received considerable attention during the last 


\section{Chem. Eur. J., 2014, 20, pp 9553-9557. doi:10.1002/chem.201402653}

decade. ${ }^{[9]}$ This interest can be explained by the new efficient synthetic methodologies recently developed. ${ }^{[10]}$ The ynamide $\mathrm{C}-\mathrm{C}$ triple bond is activated by the donating ability of the nitrogen atom (Figure 2). However, unlike ynamines, these compounds are stabilized by an electron-withdrawing group (EWG) on the nitrogen, which makes them air-stable and thus easy to handle. $[2+2]$ Cycloadditions of ynamides are known and usually require a catalyst ${ }^{[11]}$ or a Lewis acid, $^{[12]}$ except for their reaction with the ketene. ${ }^{[13]}$

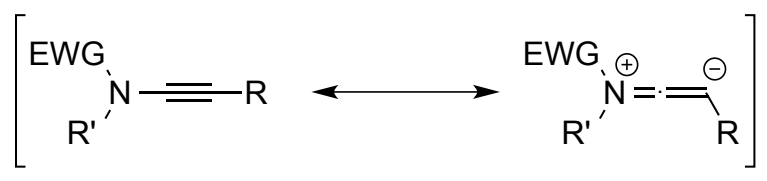

Figure 2. Ynamide mesomeric forms highlighting the electron richness of the C-C triple bond.

In this communication, we report on the reactivity of a variety of ynamides with TCNE to achieve tetracyanobutadiene (TCBD) species in moderate to excellent yields (57\% to quantitative) at room temperature and without the need for any activating agent.

At first, three different ynamides, which differ from each other by the nature of the electronwithdrawing group, were synthesized. Ynamides 1 and $\mathbf{2}$ (Scheme 1) were prepared according to literature procedures ${ }^{[14]}$ whereas the synthesis of $\mathbf{3}$ has been inspired by a recent article from the Hsung group (see Supporting Information for details). ${ }^{[15]}$ Compounds 1-3 in dichloromethane were reacted with an equimolar amount of TCNE at room temperature overnight. The same reactivity was observed and TCBD adducts 4, 5 and 6 were obtained in 92, 98 and 93\% yield, respectively. $¥$ This reaction is supposed to proceed according to a sequence of [2+2]CA-RE as described in Figure 1.
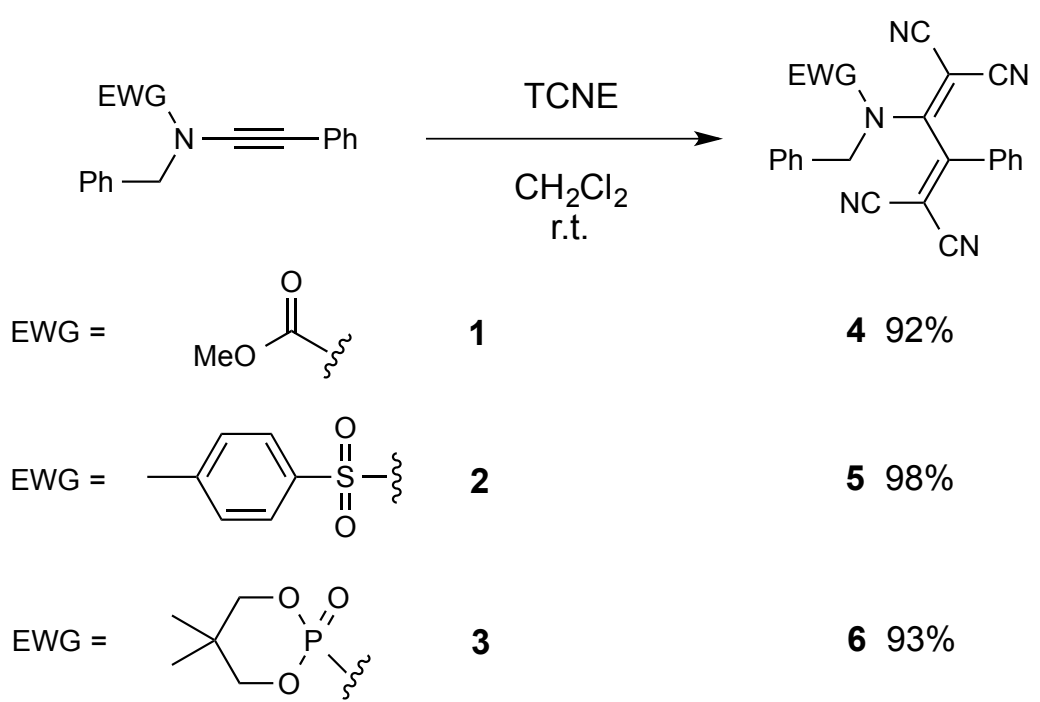

Scheme 1. Reactivity of ynamides 1-3 with TCNE giving the corresponding TCBD adducts 4-6 in excellent yields.

Secondly, the scope of the reaction was investigated using the tosylate group. This EWG was preferred over the carbamate and the phosphonate due to its ease of preparation and higher degree of crystallinity.

Table 1. Scope of the [2+2]CA-RE of ynamides and TCNE. 
Chem. Eur. J., 2014, 20, pp 9553-9557. doi:10.1002/chem.201402653
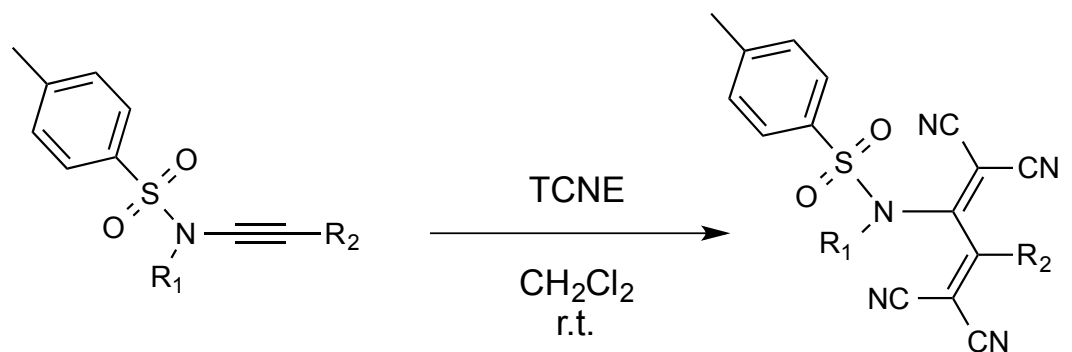

\begin{tabular}{|c|c|c|c|}
\hline Entry & Ynamide & TCBD & Yield \\
\hline 1 & $7\left(\mathrm{R}_{1}=\mathrm{CH}_{3}, \mathrm{R}_{2}=\mathrm{Ph}\right)$ & 17 & $100 \%$ \\
\hline 2 & $8\left(\mathrm{R}_{1}=\mathrm{CH}_{2} \mathrm{CH}_{2} \mathrm{Ph}, \mathrm{R}_{2}=\mathrm{Ph}\right)$ & 18 & $95 \%$ \\
\hline 3 & $9\left(\mathrm{R}_{1}=\mathrm{CH}_{2} \mathrm{Ph}, \mathrm{R}_{2}=p-\mathrm{Cl}-\mathrm{C}_{6} \mathrm{H}_{4}\right)$ & 19 & $90 \%$ \\
\hline 4 & $10\left(\mathrm{R}_{1}=\mathrm{CH}_{2} \mathrm{Ph}, \mathrm{R}_{2}=p-\mathrm{MeO}-\mathrm{C}_{6} \mathrm{H}_{4}\right)$ & 20 & $100 \%$ \\
\hline 5 & $11\left(\mathrm{R}_{1}=\mathrm{CH}_{2} \mathrm{Ph}, \mathrm{R}_{2}=p-\mathrm{NC}-\mathrm{C}_{6} \mathrm{H}_{4}\right)$ & 21 & $57 \%^{[a]}$ \\
\hline 6 & $12\left(\mathrm{R}_{1}=\mathrm{CH}_{2} \mathrm{Ph}, \mathrm{R}_{2}=p-\mathrm{Ph}_{2} \mathrm{~N}-\mathrm{C}_{6} \mathrm{H}_{4}\right)$ & 22 & $92 \%$ \\
\hline 7 & $13\left(\mathrm{R}_{1}=\mathrm{CH}_{2} \mathrm{Ph}, \mathrm{R}_{2}=\mathrm{H}\right)$ & 23 & $100 \%$ \\
\hline 8 & $14\left(\mathrm{R}_{1}=\mathrm{CH}_{2} \mathrm{Ph}, \mathrm{R}_{2}=n\right.$ hexyl $)$ & 24 & $100 \%$ \\
\hline 9 & $15\left(\mathrm{R}_{1}=\mathrm{CH}_{2} \mathrm{Ph}, \mathrm{R}_{2}=\right.$ pyridin-3-yl) & 25 & $58 \%^{[b]}$ \\
\hline 10 & $16\left(\mathrm{R}_{1}=\mathrm{CH}_{2} \mathrm{Ph}, \mathrm{R}_{2}=\right.$ thiophen-2-yl) & 26 & $87 \%$ \\
\hline
\end{tabular}

[a] using 2 eq. of TCNE, the yield was increased to 79\%; [b] 2 eq. of TCNE were used in that case, because when using 1 eq. of TCNE, an inseparable 1.8:1.0 mixture of 15:25 was obtained; when 3 eq. of TCNE were used over $64 \mathrm{~h}, \mathbf{2 5}$ was obtained in $75 \%$ yield.

Ynamides 7-16 were synthesized according to Evano's ${ }^{[10 c, 16]}$ or Hsung's $s^{[14 a]}$ procedures. The influence of the second group linked to the nitrogen $\left(R_{1}\right.$ in Table 1$)$ was first evaluated by turning it into a methyl or a homobenzylic group (entries 1 and 2). No dramatic change was observed, the yield of the reaction remaining excellent (95\% to quantitative). The influence of the group linked to the C$C$ triple bond was also evaluated. Electron-rich phenyl groups ( $p$-methoxyphenyl and $p$ diphenylaniline, entries 4 and 6 ) did not change the yield (quantitative and 92\% respectively). However, electron-poor phenyl groups ( $p$-chlorophenyl and $p$-cyanophenyl, entries 3 and 5) slightly to moderately decreased the reactivity ( $90 \%$ and $57 \%$ respectively). Nevertheless, particularly noteworthy is the significant increase of the yield with $p$-cyanophenyl group when using 2 equivalents of TCNE instead of 1 (from $57 \%$ to $79 \%$ ). The $n$-hexyl group or a hydrogen in lieu of a phenyl one provided TCBD in quantitative yields (entries 7 and 8). Heteroaromatic substituents were also studied: Whereas a thiophen-2-yl group did not really affect the yield of the reaction $(87 \%$, entry 10), a pyridin-3-yl group significantly decreased the yield to $58 \%$, even using 2 equivalents of TCNE. Indeed, 3 equivalents of TCNE and a longer reaction time of $64 \mathrm{~h}$ were necessary to give $\mathbf{2 5}$ in $\mathbf{7 5 \%}$ yield. In every instance, when the yield was not over $90 \%$, the conversion was not complete. It was never due to decomposition during the purification process.

From these figures, we can draw the conclusion that only electron-poor groups might significantly decrease the yield of the reaction in some particular cases but remain very well tolerated.

In addition, ynamide 29, bearing an azide functional group, was synthesized in $19 \%$ yield over 3 steps starting from the known azide 27 (Scheme 2) ${ }^{[17]}$ A Sonogashira coupling using (triisopropylsilyl)acetylene gave the protected alkyne $\mathbf{2 8}$ in quantitative yield and the latter was then reacted with silver fluoride and $N$-bromosuccinimide. ${ }^{[18]}$ The formed bromide derivative formed was 


\section{Chem. Eur. J., 2014, 20, pp 9553-9557. doi:10.1002/chem.201402653}

unstable, and was further reacted under Hsung's reaction condition to afford ynamide 29. Reaction with one equivalent of TCNE gave TCBD 30 in an excellent 93\% yield. This azide-functionalized TCBD 30 allows us to envisage further incorporation of new functional groups by Copper-catalyzed AzideAlkyne Cycloaddition (CuAAC) reaction ${ }^{[19]}$ for instance, as it was performed in the past with other related TCBDs. ${ }^{[20]}$

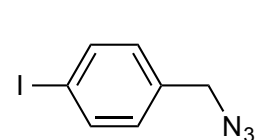

27

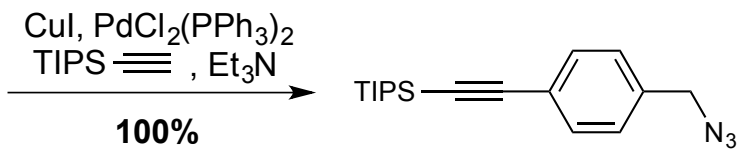

28

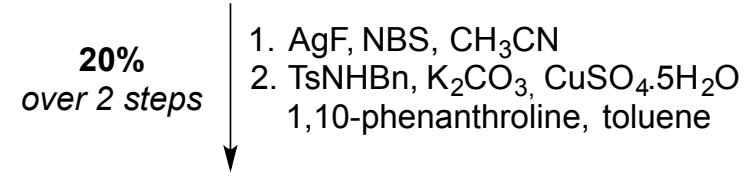

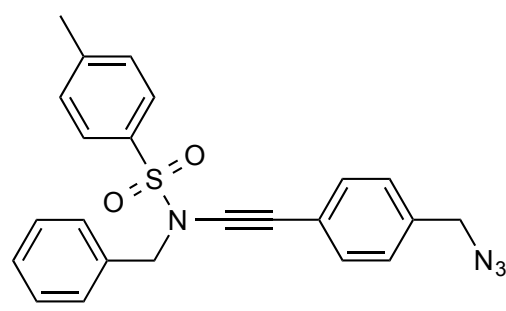

29

Scheme 2. Synthesis of ynamide 29 and further reactivity to form TCBD $\mathbf{3 0 .}$

This reactivity does not seem to be a general property of $\mathrm{N}$-substituted alkynes but a particularity of ynamides. Indeed, when reacting the commercially available ynamine $\mathbf{3 1}$ with TCNE using the same procedure as described above, a complex mixture of inseparable colored products was obtained, probably resulting from the over reaction of this very reactive compound, as it has already been described in the literature with other related compounds. ${ }^{[21]}$ By contrast, when ynehydrazide 32 ${ }^{[22]}$ was reacted with TCNE, no reaction occurred. In each case, no TCBD could be isolated. These observations led us to conclude that the right balance was found with ynamides for the reaction with TCNE to yield TCBD in high yields.

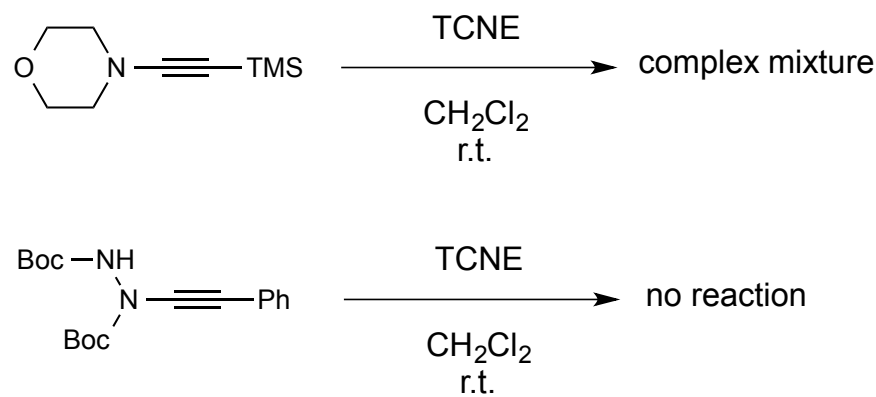

Scheme 3. Reactivity of an ynamine and an ynehydrazide with TCNE.

Products 4-6 and 17-26 were characterized by ${ }^{1} \mathrm{H}$ - and ${ }^{13} \mathrm{C}-\mathrm{NMR}$ spectroscopy, mass spectrometry, UV-vis spectroscopy and electrochemistry. Additionally, compounds 4, 5, 17, 19-22 and 25 were also characterized by X-ray diffraction, confirming unambiguously the structure of the adducts synthesized (Figure 3 and S1-S10). X-ray structures of compounds 4-5, 17, 19, 20-22 and 25 reveal 
highly distorted TCBD groups with significant twist between the two dicyanovinyl planes (Figure 3). Indeed, the torsion angle between these groups is comprised ranges between $56^{\circ}$ and $68^{\circ}$, except for compound 17 the torsion angle of which is $110^{\circ}$. The s-cis conformation in the solid state is consistent with that reported for TCBD analogs. ${ }^{[4 a, 23]}$ DFT optimized geometries both in vacuum and in solvents, suggest that the s-cis conformation is preferred in solution even though the difference with the s-trans conformation stays within a few hundreds of eV (Table S2). Both experiment and calculations evidence clearly a single bond character of the central C-C bond of the TCBD group (Table S1).

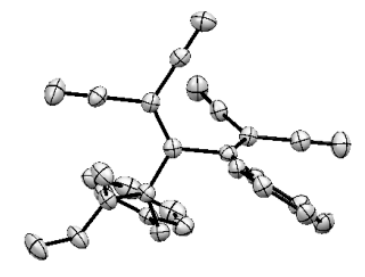

4

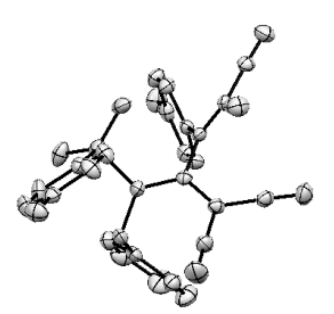

19

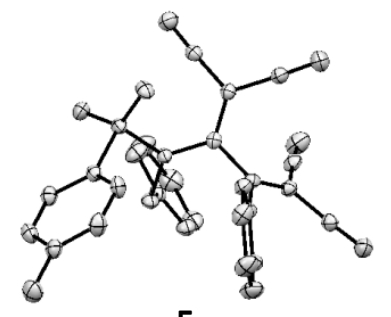

5

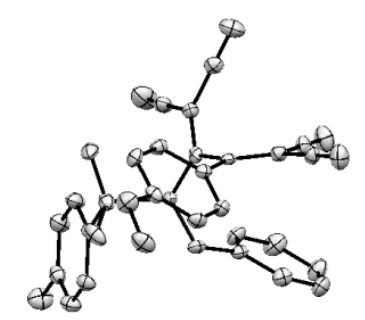

20

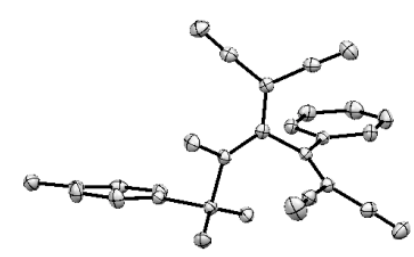

17
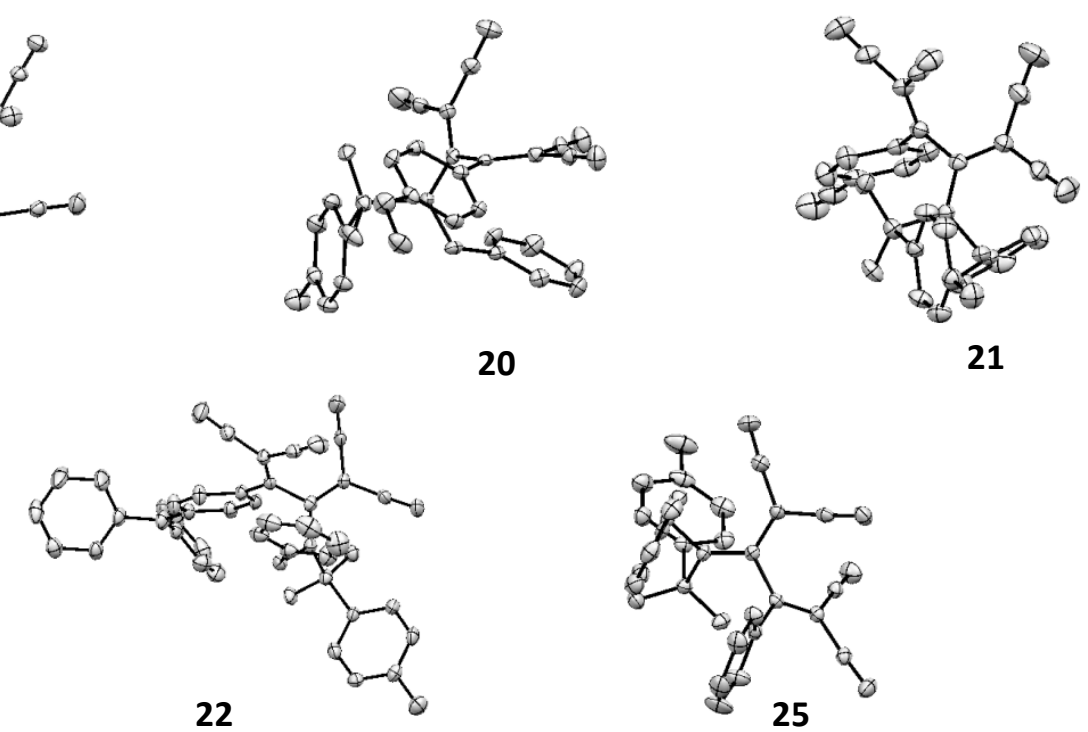

21

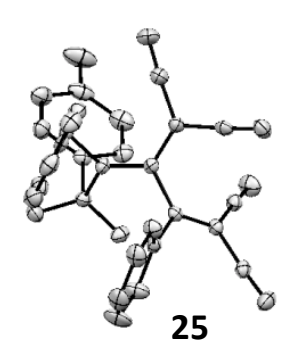

Figure 3. X-ray structures of compounds 4, 5, 17, 19-22 and $\mathbf{2 5}$. Solvent and hydrogen atoms are omitted for clarity.

UV-vis absorption spectra are shown in Figures 4 and S11-S16. Except for the donor-substituted compounds, they reveal two broad absorption bands in the UV range at ca $340 \mathrm{~nm}$ and $c a 260 \mathrm{~nm}$ with little solvatochromism indicative of non-polar ground states. TD-DFT calculations and tentative deconvolution of these optical spectra show that several electronic transitions contribute to each band (Figure S15 and Table S5). Moreover, neither the HOMO nor the HOMO-1 (Table S3) are involved in these transitions leading to the absence of absorption in the visible spectrum. Indeed, natural transition orbital ${ }^{[24]}$ plots reveal the electronic redistributions upon excitation that mainly involve the dicyanovinyl moiety connected to the phenyl ring for the first band and the other dicyanovinyl group for the second one (Table S5). Significant red shift occurs upon donor substitution with appearance of a clear isolated band in the visible range for the strongest donor (compound 22) (Figure 4). Comparison of molecular (Table S4) and transition (Table S6) orbitals of compound 22 reveal the HOMO->LUMO nature of this band, while higher-lying bright states show good correspondence with those discussed for compounds lacking donor substitution. Compounds $\mathbf{2 0}$ and 26 show an intermediary behavior due to smaller splittings between the first two excited states 
Chem. Eur. J., 2014, 20, pp 9553-9557. doi:10.1002/chem.201402653

(Table S6).

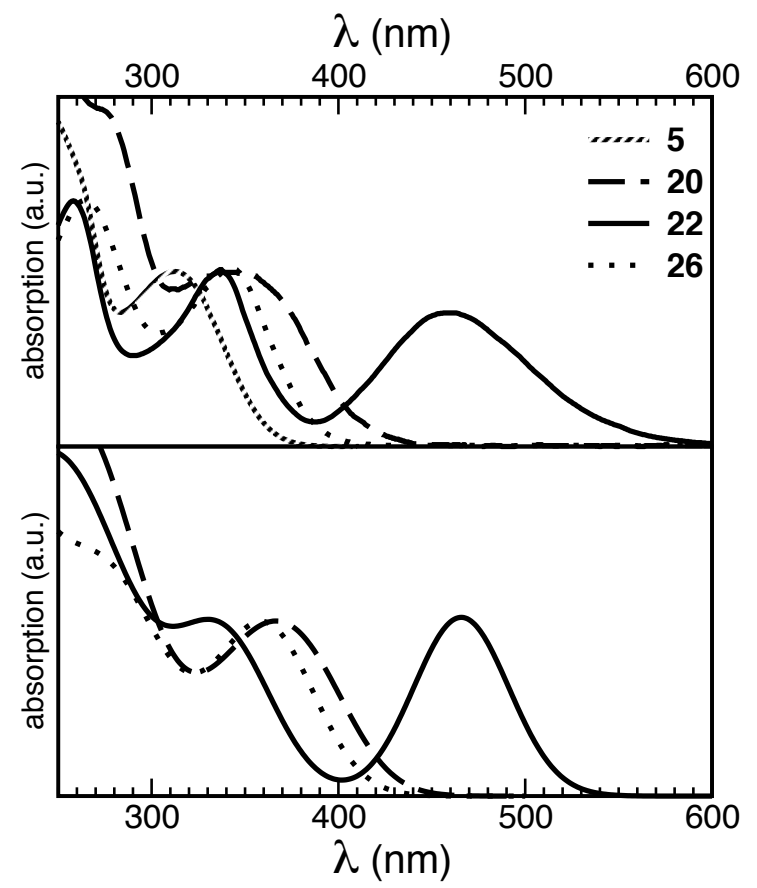

Figure 4. Experimental (top) and calculated (bottom) normalized UV-vis absorption spectra of compounds 5, 20, 22 and 26 in $\mathrm{CH}_{2} \mathrm{Cl}_{2}$. To ensure easy comparison, calculated data have been shifted by an overall offset of 0.36 eV.

In order to investigate the electronic properties of these new TCBD compounds, cyclic voltammetries were recorded in acetonitrile (Figure S17). Two distinct reversible one-electron reduction waves can be observed at approximately -0.5 and $-1.0 \mathrm{~V} \mathrm{vs} \mathrm{Fc}^{+} / \mathrm{Fc}$ (Table 2 ) that may be assigned to the subsequent reduction of the two dicyanovinyl groups. Moreover, these TCBD species are among the easiest ones to reduce out of such adducts according to the literature ${ }^{[4 a, 23]}$, making them potential super-acceptors. From these values were deduced the two electronic affinities (Table 2) for each compound (see Supporting Information for details). ${ }^{[25]}$ In addition, no oxidation could be observed (except for compound 22), in major contrast with other examples of adducts from reaction of TCNE with electron rich alkynes. ${ }^{[6 a, 7 a, 8]}$

Table 2. Measured half-wave potentials $\left(E_{1 / 2}\right)$ and electronic affinities (EA) of compounds 4-6, 20, 22 and 26 calculated on the basis of cyclic voltammetry. Acetonitrile solution of $0.1 \mathrm{~mol}^{-\mathrm{L}^{-1}}$ of $n \mathrm{Bu}_{4} \mathrm{NPF}_{6}$ and $10^{-3} \mathrm{~mol}^{-1} \mathrm{~L}^{-1}$ of TCBD at $100 \mathrm{mV} \cdot \mathrm{s}^{-1}$. DFT calculated values $\left(E A^{i, c a l}\right)$ obtained at B3LYP/6-31+G* level in acetonitrile are also reported.

\begin{tabular}{|c|c|c|c|c|c|c|}
\hline Compounds & $\mathbf{4}$ & $\mathbf{5}$ & $\mathbf{6}$ & $\mathbf{2 0}$ & $\mathbf{2 2}$ & $\mathbf{2 6}$ \\
\hline $\mathrm{E}_{1 / 2}{ }^{1}\left(\mathrm{~V}_{\mathrm{vs} \mathrm{Fc}}{ }^{+} / \mathrm{Fc}\right)$ & -0.52 & -0.54 & -0.62 & -0.58 & -0.60 & -0.52 \\
\hline $\mathrm{E}_{1 / 2}{ }^{2}(\mathrm{~V}$ vs Fc & \\
\hline $\mathrm{EA}^{1}(\mathrm{Fc})$ & -1.06 & -1.00 & -1.04 & -1.02 & -1.01 & -0.93 \\
\hline$E A^{1, c a l}(\mathrm{eV})$ & 4.32 & 4.29 & 4.21 & 4.26 & 4.24 & 4.31 \\
\hline $\mathrm{EA}^{2}(\mathrm{eV})$ & 4.54 & 4.50 & 4.37 & 4.44 & $4.28^{*}$ & 4.46 \\
\hline$E A^{2, c a l}(\mathrm{eV})$ & 3.77 & 3.83 & 3.78 & 3.81 & 3.81 & 3.90 \\
\hline
\end{tabular}

* values derived from total electronic energies instead of Gibbs free energies

From a theoretical point of view, calculated adiabatic electron affinities correlate nicely with the experimental values given in Table 2 . Electron affinities are only slightly affected by the substitutions 


\section{Chem. Eur. J., 2014, 20, pp 9553-9557. doi:10.1002/chem.201402653}

implemented in this work, the lowest value being observed with the strongest donor group (compound 22). Optimized geometries of anions evidence sizeable diminution of both the dihedral angle and the $\mathrm{C}-\mathrm{C}$ bond length between the two dicyanovinyl groups consistently with the orbital structure of the LUMO (Tables S3 and S4). This is even more pronounced for di-anions and indicates electron removal from orbitals delocalized over the whole TCBD unit. Moreover, except for 22, calculated adiabatic ionization energies in acetonitrile amount to $c a 7 \mathrm{eV}$ (Tables S7 and S9), reaching almost that of benzene. For the unsubstituted compounds, this is consistent with a HOMO mainly localized on the benzyl ring (Table S3) leading to an increased bond length alternation in their cationic forms (Table S8). Such high oxidation potentials explain that no oxidation could be observed by cyclic voltammetry in these conditions.

To conclude, an original reactivity between fourteen different ynamides and TCNE has been described. It allows for the formation of new TCBD species in good to quantitative yields by simply mixing equimolar quantities of ynamides and TCNE in dichloromethane at room temperature. These new compounds were characterized by various techniques and their properties were explained by TD-DFT calculations. In this communication, the nature of all the different functional groups of the ynamides has been investigated bringing us to the conclusion that only a strong electronwithdrawing group linked to the $\mathrm{C}-\mathrm{C}$ triple bond can affect the yield of the reaction. Moreover, this reactivity paves the way to the construction of more sophisticated systems that could exhibit interesting properties for new materials in opto-electronic devices.

\section{Notes and references}

${ }^{a}$ Ecole Nationale Supérieure de Chimie de Rennes, Institut des Sciences Chimiques de Rennes, UMR 6226, CNRS, 11 allée de Beaulieu, CS 50837, 35708 Rennes Cedex 7, France. Fax: 332232381 08; Tel: 332232380 69; E-mail: yann.trolez@ensc-rennes.fr

${ }^{b}$ Institut des Sciences Chimiques de Rennes, Université de Rennes 1, CNRS, UMR 6226, Campus de Beaulieu, 35042 Rennes Cedex, France.

†Electronic Supplementary Information (ESI) available: synthetic procedure and characterization of compounds 3-6, 12, 17-30; electrochemical analysis; computational details and results. CCDC reference numbers of compounds 3, 4, 5, 17, 19, 20, 21, 22 and 25: 905007, 881967, 884433, $960613,962305,962971,962979,966740,976260$ respectively. For ESI and crystallographic data in CIF or other electronic format see DOI: 10.1039/b000000x/

¥ Typical experimental procedure for the formation of TCBD compounds: A solution of ynamide (1.0 eq.) and tetracyanoethylene (1.0 eq.) in $\mathrm{CH}_{2} \mathrm{Cl}_{2}(0.1 \mathrm{M})$ was stirred at room temperature overnight. The solvent was evaporated, and if needed the residue was subjected to chromatography on silica gel, to afford TCBD moieties.

\section{Acknowledgements}

The authors gratefully acknowledge Dr. L. Toupet from Institut de Physique de Rennes for solving Xray structures, T. C. Nguyen for help in performing DFT calculations and Pr. A. Boucekkine for useful discussions. This work was granted access to the HPC resources of CINES and of IDRIS under the allocations 2012-[x2012080649] and 2013-[x2013080649] made by GENCl (Grand Equipement National de Calcul Intensif). N. K. acknowledges a PhD fellowship from the French Ministry of Research. M. B. thanks the Région Bretagne for a post-doctoral grant. 
Chem. Eur. J., 2014, 20, pp 9553-9557. doi:10.1002/chem.201402653

\section{References}

[1] M. I. Bruce, J. R. Rodgers, M. R. Snow, A. G. Swincer, J. Chem. Soc., Chem. Commun. 1981, 271272.

[2] M. I. Bruce, Aust. J. Chem. 2011, 64, 77-103.

[3] a) X. Wu, J. Wu, Y. Liu, A. K. Y. Jen, J. Am. Chem. Soc. 1998, 121, 472-473; b) C. Cai, I. Liakatas, M.-S. Wong, M. Bösch, C. Bosshard, P. Günter, S. Concilio, N. Tirelli, U. W. Suter, Org. Lett. 1999, 1, 1847-1849.

[4] a) T. Mochida, S. Yamazaki, J. Chem. Soc., Dalton Trans. 2002, 3559-3564; b) Y. Morioka, N. Yoshizawa, J.-i. Nishida, Y. Yamashita, Chem. Lett. 2004, 33, 1190-1191; c) S.-i. Kato, M. Kivala, W. B. Schweizer, C. Boudon, J.-P. Gisselbrecht, F. Diederich, Chem. Eur. J. 2009, 15, 8687-8691; d) D. Koszelewski, A. Nowak-Król, D. T. Gryko, Chem. Asian J. 2012, 7, 1887-1894; e) R. García, M. Á. Herranz, M. R. Torres, P.-A. Bouit, J. L. Delgado, J. Calbo, P. M. Viruela, E. Ortí, N. Martín, J. Org. Chem. 2012, 77, 10707-10717.

[5] a) S.-i. Kato, F. Diederich, Chem. Commun. 2010, 46, 1994-2006; b) B. Breiten, M. Jordan, D. Taura, M. Zalibera, M. Griesser, D. Confortin, C. Boudon, J.-P. Gisselbrecht, W. B. Schweizer, G. Gescheidt, F. Diederich, J. Org. Chem. 2013, 78, 1760-1767.

[6] a) T. Michinobu, J. C. May, J. H. Lim, C. Boudon, J.-P. Gisselbrecht, P. Seiler, M. Gross, I. Biaggio, F. Diederich, Chem. Commun. 2005, 737-739; b) X. Tang, W. Liu, J. Wu, C.-S. Lee, J. You, P. Wang, J. Org. Chem. 2010, 75, 7273-7278.

[7] a) T. Shoji, S. Ito, K. Toyota, M. Yasunami, N. Morita, Chem. Eur. J. 2008, 14, 8398-8408; b) T. Shoji, E. Shimomura, M. Maruyama, A. Maruyama, S. Ito, T. Okujima, K. Toyota, N. Morita, Eur. J. Org. Chem. 2013, 2013, 7785-7799.

[8] T. Shoji, J. Higashi, S. Ito, T. Okujima, M. Yasunami, N. Morita, Chem. Eur. J. 2011, 17, 51165129.

[9] a) G. Evano, A. Coste, K. Jouvin, Angew. Chem. Int. Ed. 2010, 49, 2840-2859; b) K. A. DeKorver, H. Li, A. G. Lohse, R. Hayashi, Z. Lu, Y. Zhang, R. P. Hsung, Chem. Rev. 2010, 110, 5064-5106.

[10] a) M. O. Frederick, J. A. Mulder, M. R. Tracey, R. P. Hsung, J. Huang, K. C. M. Kurtz, L. Shen, C. J. Douglas, J. Am. Chem. Soc. 2003, 125, 2368-2369; b) T. Hamada, X. Ye, S. S. Stahl, J. Am. Chem. Soc. 2008, 130, 833-835; c) A. Coste, G. Karthikeyan, F. Couty, G. Evano, Angew. Chem. Int. Ed. 2009, 48, 4381-4385.

[11] N. Riddell, K. Villeneuve, W. Tam, Org. Lett. 2005, 7, 3681-3684.

[12] a) K. C. M. Kurtz, R. P. Hsung, Y. Zhang, Org. Lett. 2006, 8, 231-234; b) L. You, Z. F. Al-Rashid, R. Figueroa, S. K. Ghosh, G. Li, T. Lu, R. P. Hsung, Synlett 2007, 1656-1662.

[13] a) A. L. Kohnen, X. Y. Mak, T. Y. Lam, J. R. Dunetz, R. L. Danheiser, Tetrahedron 2006, 62, 38153822; b) Y.-P. Wang, R. L. Danheiser, Tetrahedron Lett. 2011, 52, 2111-2114.

[14] a) Y. Zhang, R. P. Hsung, M. R. Tracey, K. C. M. Kurtz, E. L. Vera, Org. Lett. 2004, 6, 1151-1154; b) C.-F. Xu, M. Xu, Y.-X. Jia, C.-Y. Li, Org. Lett. 2011, 13, 1556-1559.

[15] K. A. DeKorver, M. C. Walton, T. D. North, R. P. Hsung, Org. Lett. 2011, 13, 4862-4865.

[16] K. Jouvin, A. Coste, A. Bayle, F. Legrand, G. Karthikeyan, K. Tadiparthi, G. Evano, Organometallics 2012, 31, 7933-7947.

[17] J. Lee, S.-U. Kang, J.-O. Lim, H.-K. Choi, M.-k. Jin, A. Toth, L. V. Pearce, R. Tran, Y. Wang, T. Szabo, P. M. Blumberg, Bioorg. Med. Chem. 2004, 12, 371-385.

[18] T. Lee, H. R. Kang, S. Kim, S. Kim, Tetrahedron 2006, 62, 4081-4085.

[19] a) V. V. Rostovtsev, L. G. Green, V. V. Fokin, K. B. Sharpless, Angew. Chem. Int. Ed. 2002, 41, 2596-2599; b) C. W. Tornøe, C. Christensen, M. Meldal, J. Org. Chem. 2002, 67, 3057-3064.

[20] Y. Li, T. Michinobu, Polym. Chem. 2010, 1, 72-74.

[21] G. Jayamurugan, J.-P. Gisselbrecht, C. Boudon, F. Schoenebeck, W. B. Schweizer, B. Bernet, F. Diederich, Chem. Commun. 2011, 47, 4520-4522.

[22] R. E. Beveridge, R. A. Batey, Org. Lett. 2012, 14, 540-543. 
Chem. Eur. J., 2014, 20, pp 9553-9557. doi:10.1002/chem.201402653

[23] T. Michinobu, C. Boudon, J.-P. Gisselbrecht, P. Seiler, B. Frank, N. N. P. Moonen, M. Gross, F. Diederich, Chem. Eur. J. 2006, 12, 1889-1905.

[24] R. L. Martin, J. Chem. Phys. 2003, 118, 4775-4777.

[25] a) J. L. Bredas, R. Silbey, D. S. Boudreaux, R. R. Chance, J. Am. Chem. Soc. 1983, 105, 6555-6559;

b) S. Trasatti, J. Electroanal. Chem. Interfacial Electrochem. 1983, 150, 1-15; c) Q. Xie, S. Kuwabata, H. Yoneyama, J. Electroanal. Chem. 1997, 420, 219-225. 